\title{
Possibly Better
}

National Cancer Institute

\section{Source}

National Cancer Institute. Possibly Better. NCI Thesaurus. Code C53560.

Showing signs suggestive of improvement. 